\title{
Mycoplasma Pneumoniae Infection: A Case Requiring Follow-Up in Intensive Care Unit
}

\author{
Gökhan Perincek ${ }^{1}$, Sema Avcı ${ }^{2 *}$, Emrah Batmaz ${ }^{3}$ \\ ${ }^{1}$ Department of Chest Diseases, Kars Harakani State Hospital, Turkey \\ ${ }^{2}$ Department of Emergency Medicine, Amasya University, Sabuncuoglu Serefeddin Research and Training Hospital, Turkey \\ ${ }^{3}$ Department of Chest Diseases, Tekirdag State Hospital, Turkey
}

Submission: November 08, 2018; Published: December 03, 2018

*Corresponding author: Sema Avci, Amasya University, Sabuncuoğlu Şerefeddin Research and Training Hospital, Department of Emergency Medicine, Amasya, Turkey

\section{Case Report}

The community-acquired pneumonia due to Mycoplasma pneumoniae is usually mild. Severe life-threatening pneumonia is rare due to this kind of infection. Our case was a 50-year-old healthy male patient. Patient with bilateral pneumonia, acute respiratory failure and high fever was followed in the intensive care unit and noninvasive mechanical ventilation was performed. IFAT Mycoplasma species IgM 1/80 were positive. This case report shows that community acquired pneumonia with acute respiratory failure is not seen only elderly and immuncompromised patients. This kind of pneumonia may also seen in healthy adults.

A 50-year-old man admitted to emergency room with high fever, cough, sputum, headache and dyspnea. The patient's medical history and family history were unremarkable. Smoking status was active. On respiratory system examination, tuber sufl on the right middle zone, and inspiratory rales were revealed on the left lung middle side. The patient's blood pressure was $80 / 40 \mathrm{mmHg}$,

pulse was $105 /$ beats per minute, fever was $39^{\circ} \mathrm{C}$, respiratory per minute was 34 and oxygen saturation on finger monitor was $74 \%$. The patient with moderate general status was admitted to the intensive care unit.

Laboratory examination: White blood cell $20.1\left(10^{9} / \mathrm{L}\right)$, C-reactive protein: $37.9 \mathrm{mg} / \mathrm{dL}$ and sedimentation $95 \mathrm{~mm} / \mathrm{h}$. There was no growth in blood culture, urine culture and sputum culture. IFAT Chlamydiae: Negative. IFAT Mycoplasma IgM 1/10 $(+), 1 / 20(+), 1 / 40(+), 1 / 80(+)$. Electrocardiogram was sinus rhythm. Chest x-ray showed pneumonic consolidation with air bronchogram in bilateral middle and lower zones (Figure 1). Double antibiotic treatment was started. Non-invasive mechanical ventilation was performed for 3 days in intensive care unit. A significant improvement in chest x-rays taken on day 3 and 10 of treatment (Figures $2 \& 3$ ). The aim of this case report is to show the serious results of mycoplasma infection in a healthy individual.

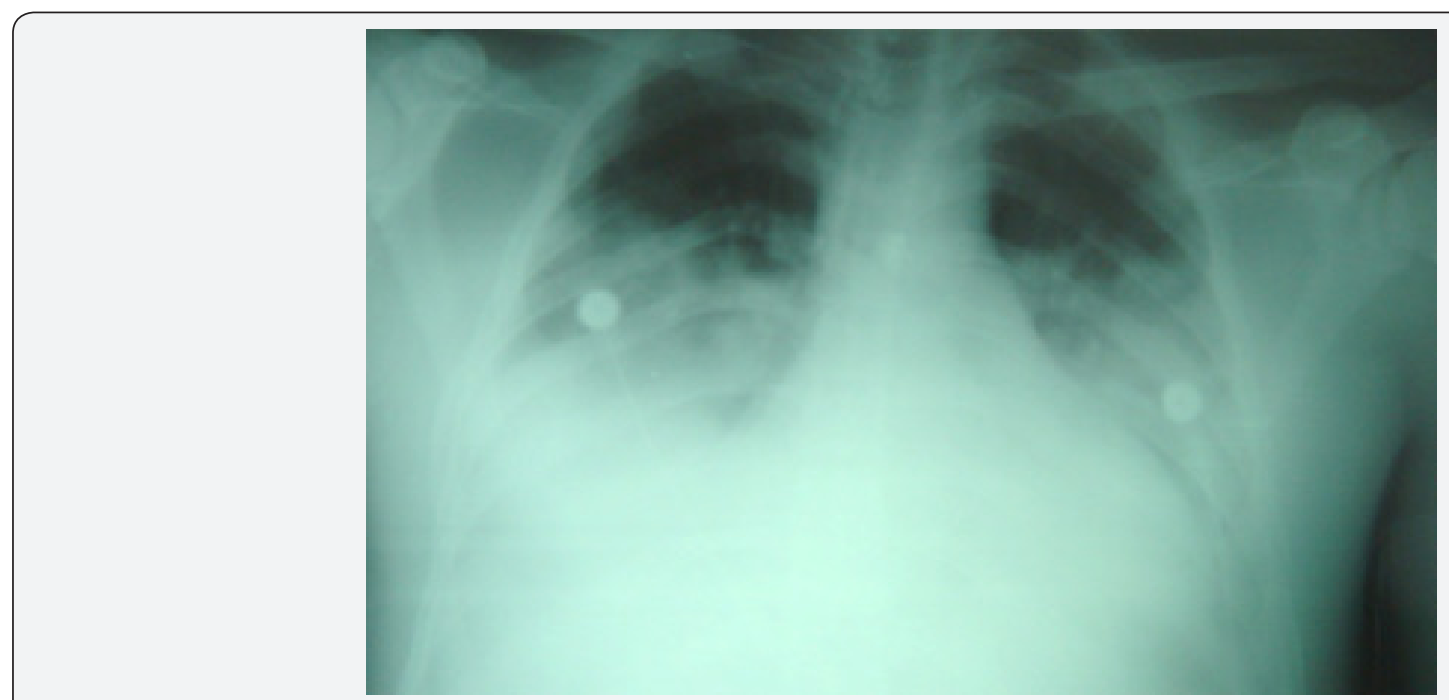

Figure 1: Chest x-ray on admission. 


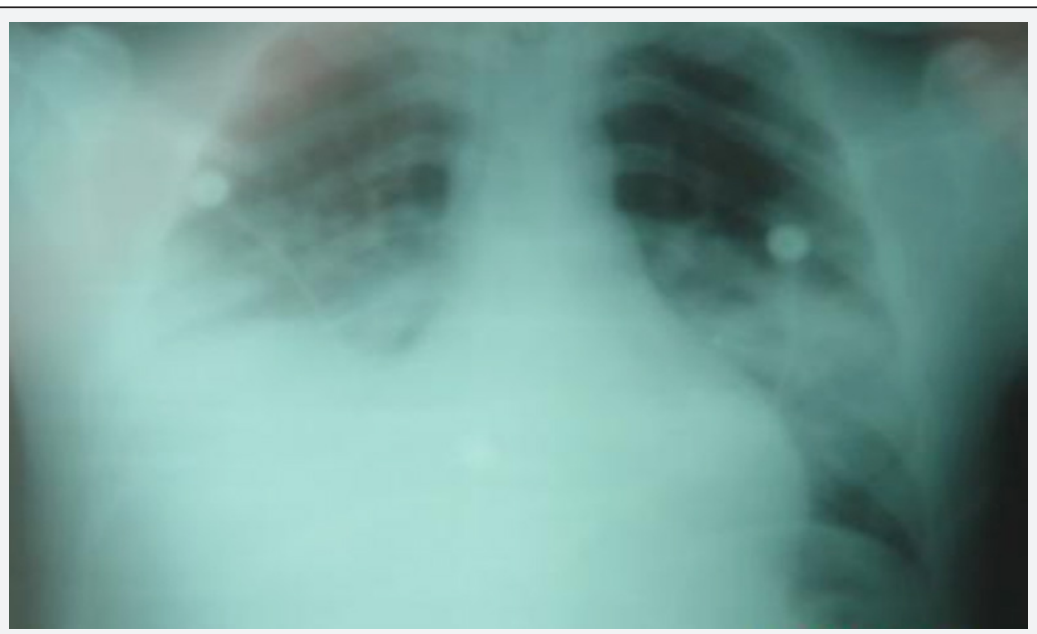

Figure 2: On the $3^{\text {rd }}$ day of treatment.

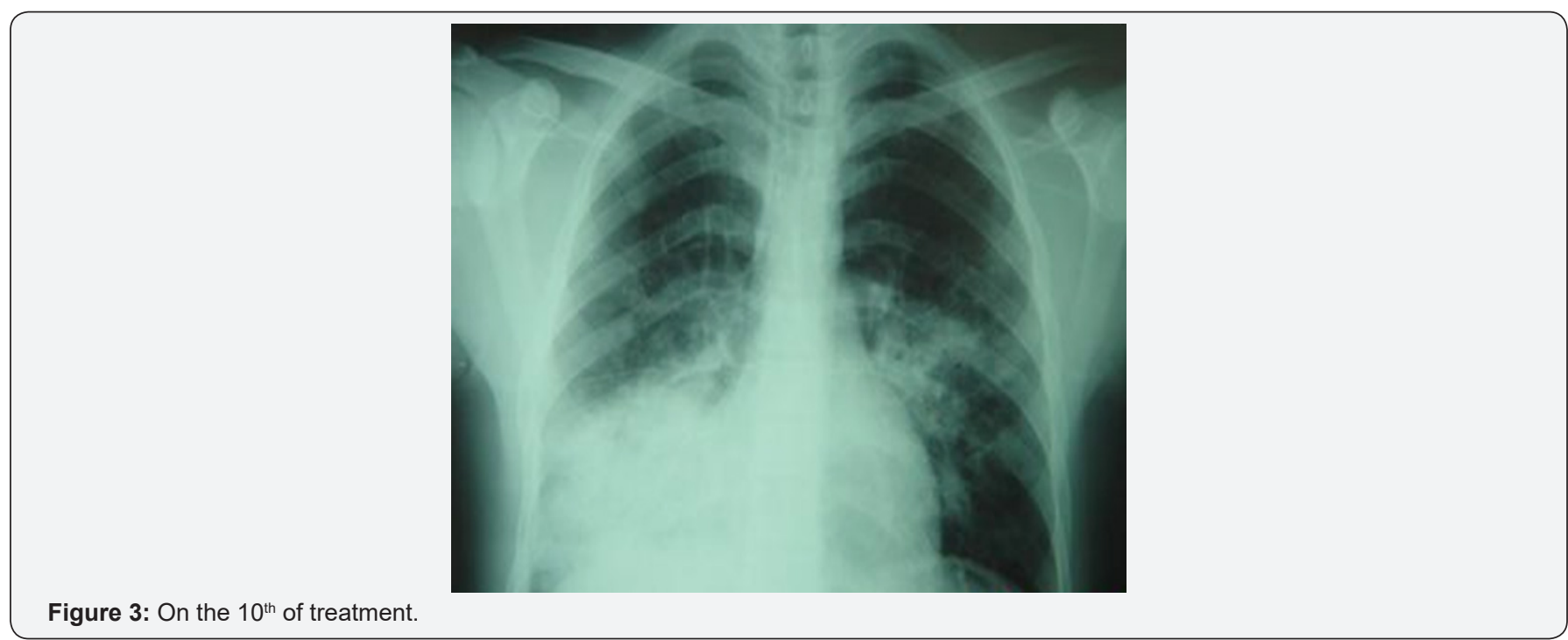

\section{Conflict of Interest}

All the authors declare that they have all participated in the design, execution, and analysis of the paper, and that they have approved the final version. Additionally, there are no conflicts of interest in connection with this paper.

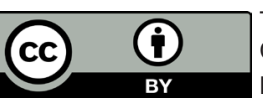

This work is licensed under Creative Commons Attribution 4.0 License DOI: 10.19080/JAICM.2018.08.555726

\section{Financial disclosure}

The authors have no funding to disclose.

\section{Your next submission with Juniper Publishers will reach you the below assets}

- Quality Editorial service

- Swift Peer Review

- Reprints availability

- E-prints Service

- Manuscript Podcast for convenient understanding

- Global attainment for your research

- Manuscript accessibility in different formats ( Pdf, E-pub, Full Text, Audio)

- Unceasing customer service

Track the below URL for one-step submission https://juniperpublishers.com/online-submission.php 